ISSN 2080-1653

DOI 10.24917/20801653.353.5

\author{
ZHANNA BUCHKo \\ Yury Fedkovych Chernivtsi National University, Chernivtsi, Ukraine
}

\title{
Transborder recreational tourism complexes (TBRTC) as a result of international collaboration
}

\begin{abstract}
The paper discusses the notion of a transborder recreational tourism complex (TBRTC) as a geographic and as a wider multidisciplinary concept and describes such complexes within transborder tourism regions in Western Ukraine. A TBRTC is introduced as a spatial formation that arises within tourism-specific transborder collaboration. A TBRTC combines three necessary components: the entirety of all tourism-attracting resources in a specific transborder region; the travel-enabling infrastructure, including transborder-specific features like border-crossing checkpoints; and informational and coordination resources such as tour operating services and defined tourist routes. The paper explains basic terminology and key principles for formation and existence of TBRTCs. The authors start by explaining the unique characteristics of transborder tourism in Europe and in tourism-oriented formations called Euro-zones. A principal model of TBRTC is proposed, including the list of factors necessary for its formation, the key structural modules of a complex; and the causal connectivity map between these modules applied to different types of tourism. The concept of a TBRTC is illustrated using the example of the TBRTC forming in Bukovina-Bessarabia transborder region along part of Ukraine-Romania-Moldova border. This region offers multiple types of tourism activities, which translates into the emergence of a robust transborder tourism recreation complex that started forming in the late 1990 s and continues to be shaped until this time.
\end{abstract}

Keywords: Euro-Region; recreational tourism complex; tourism; transborder cooperation; transborder tourism

Received: 18 April 2021

Accepted: 4 June 2021

\section{Suggested citation:}

Buchko, Z. (2021). Transborder recreational tourism complexes (TBRTC) as a result of international collaboration. Prace Komisji Geografii Przemystu Polskiego Towarzystwa Geograficznego [Studies of the Industrial Geography Commission of the Polish Geographical Society], 35(3),76-89, doi: https://doi.org/ 10.24917/20801653.353.5

\section{INTRODUCTION}

Transborder tourism is a subclass of international tourism that includes travelling across the border of neighbouring countries and significant presence of the traveller in the near-border region with recreational, health and wellness, educational or other 
motives and without performing paid work. Geography literature uses both "transborder tourism" and "cross-border tourism" in similar contexts, e.g. Leimgruber (1998) and Gramberger (1999). We will consistently adhere to the former term.

The objectives of transborder tourism research are analysis and systematisation of origins, advancement, and operation of tourism in near-border territories. Geographical features of such areas create unique ways of economic and cultural development through implementation of various forms of transborder collaboration between neighbours. These factors contribute to the development of robust tourism services market, especially with additional support from the government and in open economic environment (Gramberger, 1999; Boonchai and Freathy, 2020). Convenient territorial location and rich historical and cultural resources make Ukraine a prime candidate for developing transborder tourism.

An important concept partially overlapping with tourism is transborder collaboration: combination of all political, cultural, commercial, or other societal activities that occur on both sides of the border of neighbouring countries and pursue common or coordinated goals, as described both in more general works cited above and on a specific example of destination marketing in Kozak and Buhalis (2019).

International tourism research in Eastern Europe has been presented in a range of publications in the fields of geography, economics, and political science. In particular, Livandovschi (2017) studied cross-border tourism and its significance for tourism destinations. Pirozhnik (2020) studied tourism clusters as a factor in activating cross-border spatial development. Summary studies of transborder collaboration in several Eastern European countries are presented in Więckowski (2010), Rudawska and Fedorowski (2016), Żemła and Ziółkowska-Weiss (2017), Dołzbłasz (2018), Więckowski and Saarinen (2019), Korol and Skutar (2019).

Polish-Slovak border tourism was studied by Klamár and Mika (2015), Buczek-Kowalik and Mitura (2018); Polish-Russian border tourism by Studzieniecki, Palmowski and Korneevetsc (2016). Examples of published research on cross-border collaborations in Poland include Polish-German border tourism analysis by Krätke (2002), Ried and Marschall (2016), Studzieniecki and Spiriajevas (2019). Cross-border cooperation between Poland and Czechia and the development of the tourism functions of the region was analysed by Kołodziejczyk (2020).

This paper relies on the constructive geography work on transborder tourism previously published by us, including work on Ukraine-Romania transborder collaboration (Buchko 2018), Ukraine-Hungary transborder collaboration (Bozhuk and Buchko, 2018), and Ukraine-Poland collaboration (Buchko 2020). Prior research on tourism in Northern Romania is presented in Buchko (2015) and in Tătar et al (2020).

In this paper, we focus on transborder recreation-tourism complexes (TBRTCs), socio-economic structures that arise as the result of travel-related transborder collaboration. We define what TBRTCs are and explain how they play the vital role in sustaining and growing tourist-oriented market and tourism in general. We focus on TBRTCs that arise in Ukraine in the context of the country's Euro-integration and the growth of Ukraine's attractiveness as an international tourism destination.

The aim of our work is to introduce and develop the notion of a TBRTC as a convenient systematising tool for understanding the role of transborder tourism in economic, cultural, and political aspects of life in near-border regions, and illustrate the new concept using an example. The main research questions are answered in the three separate 
sections of the main body of this article: what are transborder tourism and transborder collaborations; what are the definition and key components of a TBRTC; and how a TBRTC is formed, explained based on an existing example.

\section{METHODS AND DATA SOURCES}

The object of the research is the combination of general principles of formation and territorial organisation of TBRTCs and their impact on Euro-integration and sustained development of tourism in Ukraine. Our research of geospatial structure of transborder tourism has been performed using both systems approach and territorial approach. More specifically, our work is structured in the following way: first, we consider the specific features of transborder tourism and systematise its key distinctions from other types of tourism. The notion of a Euro-region is explained in that context. Next, we justify the introduction of transborder recreation-tourism complex as the unifying concept of tourism-related economy and politics. In addition to defining a complex, we itemize the factors that influence the formation of a TBRTC, the different types of tourism that contribute to it, and describe in detail all of its components. Finally, we elaborate on all of the proposed definitions and systematisations by applying them to the real-life example of Bukovina-Bessarabia transborder region in Ukraine, Romania, and Moldova.

The data sources of the proposed document include information from the literature, including several earlier works from the author, and analysis of formal policy documents published by the government of Ukraine: Ukraine's Cabinet of Ministers-approved "Strategy of development of tourism and recreation until 2026", "State strategy of transborder collaboration development for 2021-2027", "State strategy of regional development until 2027", "Strategy project of sustained development of Ukraine until 2030", all four documents are listed in the Bibliography by their titles.

\section{TRANSBORDER TOURISM IN UKRAINE}

As stated in the introduction, transborder tourism is a sub-category of tourism, which occurs in direct vicinity of state borders and extends across these borders, thus having interterritorial, interregional, and transborder qualities. It is more than a mere fact of travelling across the border to seek recreation in another country. It must involve tourism activities in the transborder territory, whereas crossing the border is only a necessary requirement.

Transborder tourism is both a benefactor and a driver of transborder collaboration. Applied to tourism, transborder collaboration encompasses a range of commercial, social, and cultural activities focused on developing the necessary infrastructure and on creation and maintenance of designated tourist routes in transborder and neighbouring regions. Infrastructure development, demand for tourism-specific services, and new customer base increase profitability of local businesses and bring positive change to the regions. Overall, tourism-related collaboration is an important mechanism for establishing and strengthening international relations, both political and economic.

Transborder tourism research focuses on characteristic features of the specific region being studied. How transborder tourism region is formed is determined by a complex and interconnected set of natural, socioeconomic, and psychological factors. Natural factors ensure the geographical possibility to create continuous and logical 


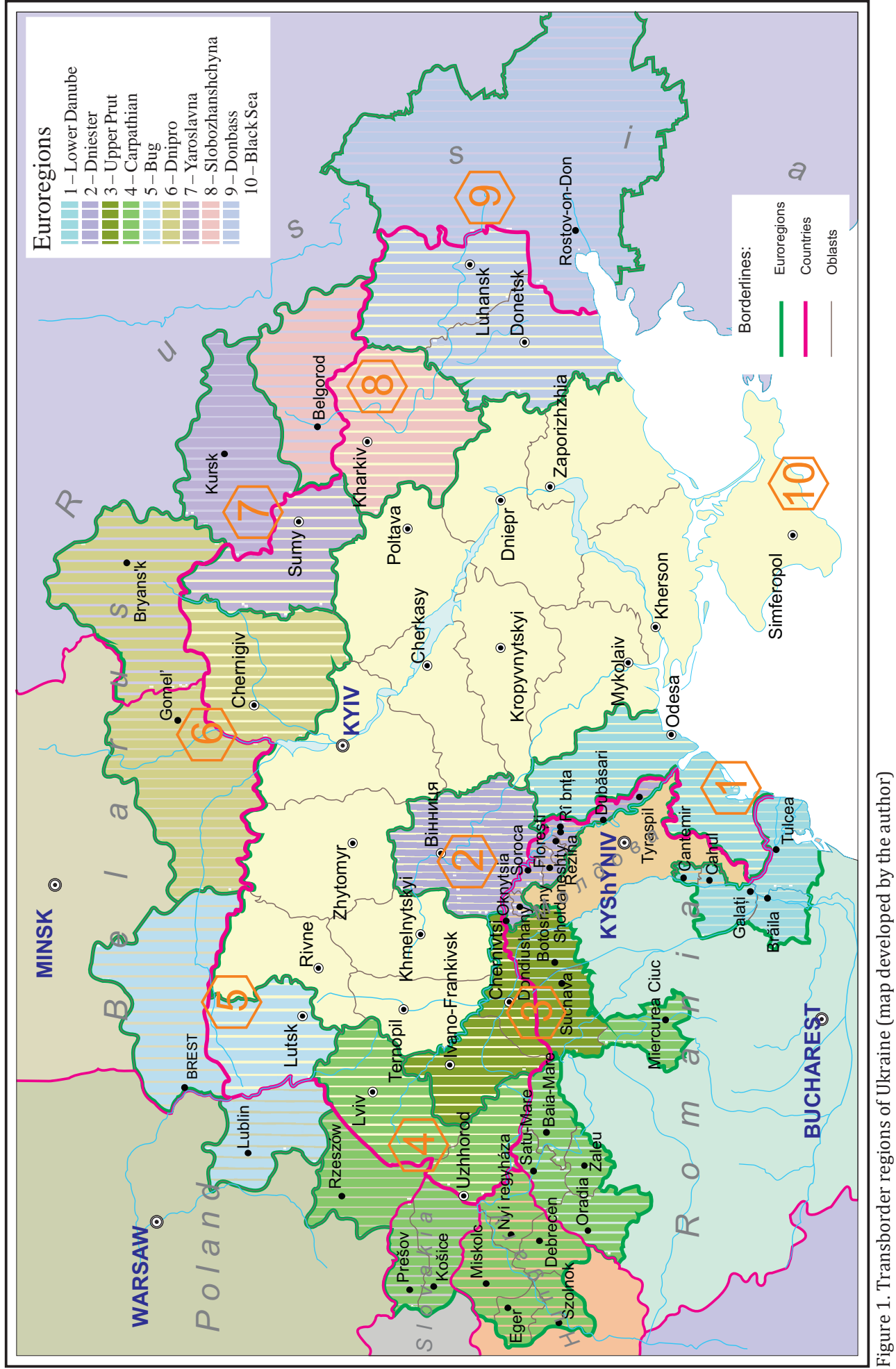


recreational tourist complexes. Socioeconomics factors support the homogeneity of transborder space by synchronising the development of tourism infrastructure and maintaining active tourist flows (Stoffelen, 2017). Psychological factors define the demand for products and resources in neighbouring regions (Stoffelent, Vanneste, 2019; Karatabanov, Janaleyeva, Pashkov, 2020).

A commonly used concept important for understanding tourism in Europe is a Euro-region: a territorial formation within parts of one or more countries, which is held together by historical, social, political, economic, or nature-related links ("Regulation (EC)", 2006). Ten Euro-regions has been created along the borders of Ukraine in 19932015: Bug, Upper Prut, Lower Danube, Carpathians, Dnipro, Slobozhanshchyna, Yaroslavna, Donbass, Dniester, and Black Sea (Mikula, 2006). Each of these regions defines the organisational form of collaboration between administrative-territorial units of the bordering countries. These regions are created within Vinnytsia, Volhynian, Donetsk, Transcarpathian, Ivano-Frankivsk, Luhansk, Lviv, Odessa, Sumy, Kharkiv, Chernivtsi, and Chernihiv regions (Fig. 1).

Recreation and tourism are identified as important directions of transborder collaboration for most of the Euro-regions in Ukraine. Preservation of cultural and natural heritage as significant tourism resources is an important subcomponent of regional policy, especially in Euro-regions of Upper Prut, Carpathians, and Bug. For a range of Euro-regions, particularly, in Western Ukraine, an important factor is taking into account local ethno-cultural traditions when organising tourism services. In all of the Euro-regions, a key direction of tourism development is improving the necessary infrastructure: roads and public transport, food service, and boarding. Another pressing issue is the development of border-crossing infrastructure such as checkpoints with simplified crossing procedures, such as pedestrian-only checkpoints.

Euro-regions such as Bug, Upper Prut, Lower Danube and Carpathians are poised to support the development of transborder folklore, cultural, ethnic, religious, rural, and ecological kinds of tourism as the most effective ways of utilising unique landscape-recreational potential of the region. In these Euro-regions, tourism is a major source of employment and a major factor in attracting foreign investments and credits, a vehicle for adapting business experience from the foreign partners, and a driver for developing transportation and other infrastructure. To large extent, Euro-regions define local and regional politics related to transborder collaboration.

At this stage, the government of Ukraine started developing the "Concepts of strategic development of transborder regions", which includes European-wide, national, and regional priorities. These "Concepts" are built taking into account regionals and state-wide strategies of socioeconomic development.

\section{TRANSBORDER RECREATION TOURISM COMPLEXES}

A general recreation-tourism complex (RTC) is a combination of geographical features and commercial and administrative structures within a tourist destination region. One can claim that an RTC has formed if a territory has a combination of (a) tourist-attracting resources; (b) infrastructure to support tourist flows; and (c) travel information and coordination structures. A transborder recreation-tourism complex (TBRTC) is an extension of the above concept to transborder tourism. An RTC within a single country may arise on its own provided open and robust economy that can respond to market 
demand by forming material and information infrastructure around a tourist attraction. In transborder case, the infrastructural challenges are multiplied manyfold, which isolates TBRTCs into a separate category that needs to be studied on its own.

A TBRTC is both the result of transborder collaboration in support of tourism and travel and a key factor for sustaining and growing tourism activity. Such a complex arises when a transborder area has natural, cultural, commercial or other resources that can draw in visitors. The material infrastructure necessary to support travellers includes both standard factors such as food and accommodation services and local transportation, and special challenges such as international transportation and border crossing checkpoints. Similarly, informational infrastructure development requires collaboration of different countries' administrations and coordination of local structures on both sides of the border. Any structures that aid transborder collaboration such as Euro-regions or international tourism development programs help to solve these infrastructural challenges. In Figure 2, we summarise the causal flow of forming of TBRTCs in Ukraine and its neighbours.

Figure 2. Transborder tourism within wider transborder collaboration (graphics developed by the author)

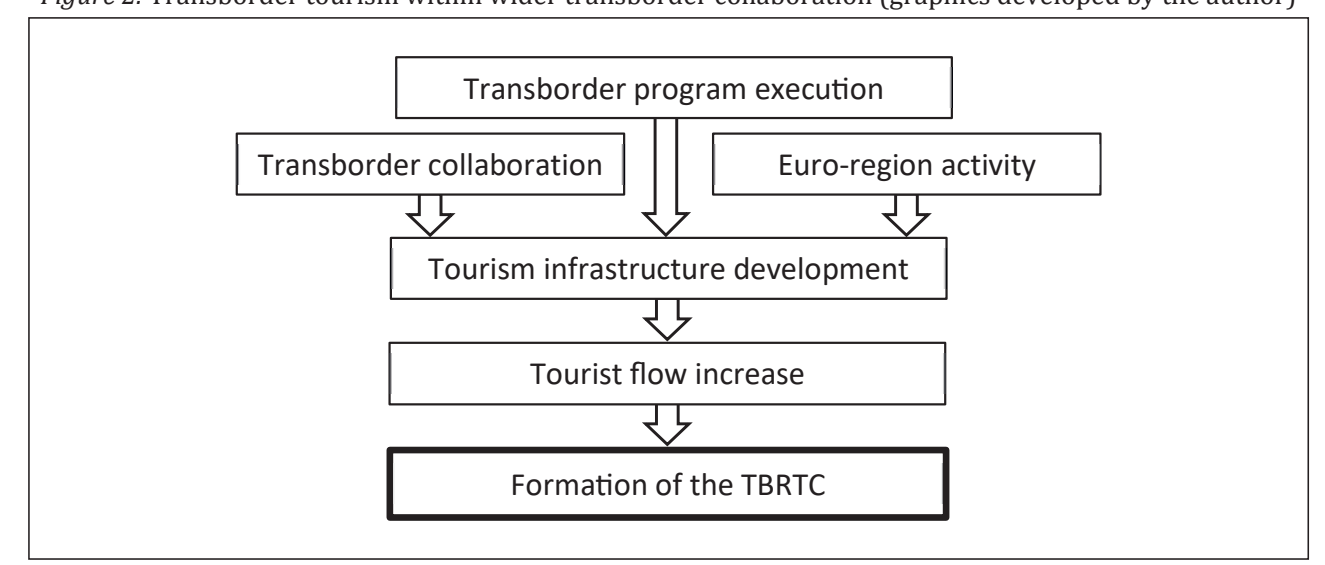

Source: graphics developed by the author

Formation of a TBRTC depends on a range of factors, both external and internal, further subdivided by the type of impact. We propose the following categorisation to describe the influencing factors of transborder recreational tourism complex formation:

\section{External (exogenous) factors:}

- Demographic changes including changes in age distribution, urban/rural population distribution, and ethnic and racial distributions due to migration. Such changes impact both the availability and cost of labour for tourism-oriented businesses and the existence and buying power of local consumers and potential tourists.

- Socio-financial changes, such as changes in buying power of people due to changes in personal wealth of both visitors and the local population, as well as changes in access and types of external capital.

- Socioeconomic changes are the transformations in the society influenced by shifts in incomes and types of occupation, as well as changes in popular priorities of spending time and other resources. A good example of such factor is how a change in a typical 
work week structure may translate into increased (or decreased) ability to travel locally as a tourist or to join a small business that would service tourists.

- Political and legal changes include more formal aspects of the ongoing transition from the old socialist and early post-socialist systems, as well as more recent legislative developments such as changes in laws and policies in response to new social and environmental challenges.

- Technological changes include both developments that impact travel directly, such as GPS and online map technology driving the change in tourist route access and need for guides, and all indirect influences such as implicit expectation of broadband Internet access or electric-car-charging infrastructure availability.

- Euro-integration processes include aspects of all of the above, directed at modern region-formation processes dictated by the unique European political dynamic of peaceful and voluntary re-integration of previously divided societies. Local tourism is often the first step in such reintegration. One can argue that significant increase in tourist flows, including transborder tourists, was an important stage in the process which culminated in adding new European Union members.

\section{Internal (endogenous) factors}

- Extensive factors (scale growth):

- Workforce growth due to demographic changes and changes in the structure of local economies. This factor directly mirrors the above-mentioned endogenous demographic changes explanation with the only distinction being that the changes are internal and not caused by migration.

- Tourism-related capital investment growth from all sources, state, local, and international investors.

- New tourist destinations and attractions discovered, created, or moved to a specific tourism-target region. This can include both developing existing resources into tourist attractions such as restoring an ancient castle or temple, or building tourist-attracting businesses such as amusement parks, health resorts, or shopping malls.

- Intensive factors (productivity growth):

- Improvement in personnel skills in local tourism services can either occur "naturally" through accumulation of experience, translation of experience from other locations, or via targeted education in tourism-related trades.

- Development of professional qualification certification structure, either local or trans-national, ranging from restaurant ratings to ski instructor certifications.

- Diversification of the spectrum of tourism-related services can either occur locally as businesses respond to new demands or be driven by larger entities, either governmental or corporate, an example of the latter being a hotel or a restaurant chain moving into the region.

- Rational use of existing material resources such as renewable and low-footprint outdoor tourism. Transborder tourism is often encouraging preservation and restoration of local cultural and historic heritage by increasing demand for products of historically existing crafts and trades; providing motivation to recover and sustain local musical and dance traditions; and so on. 


\section{- Impeding factors:}

- Political and/or financial instability, unfortunately still prevalent across Eastern Europe with cases of high inflation or frequent power structure overhauls made possible by the lack of political culture and tradition.

- Unemployment impacts the tourism primarily by driving down the safety and well-being of the region, thus reducing its attractiveness as a tourist destination.

- Adverse ecological/environmental changes driven by climate change, and non-sustainable agricultural or industrial activity. This includes both the increased caution of potential travellers because of chemical or radioactive pollution and impact of environmental factors on infrastructure, for example, bridges and roads ruined by floods caused by climate change.

- Local military conflicts and their consequences such as increased refugee flows. In the case of Ukraine, the annexation of Crimea and Russia-supported separatist war in Donbass impacted tourism even in parts of the country that are far away from the location of military activities.

- Inadequate border-crossing infrastructure, potentially the hardest of all logistical challenges, as it requires coordinated structural, administrative, and legislative efforts from both participating countries.

In terms of their functionality, we propose to categorise the components of a TBRTC as basic and complementary, as listed below. Most of these components are self-explanatory, for some of the potentially vague ones we provide a brief clarification:

\section{List of functional components of a TBRTC}

- Basic infrastructure

- Tour-operating services

- Boarding accommodation facilities

- Food establishments

- Travel information services

- Recreational complexes (combined delivery of entertainment or other recreational services and all or any of the components above it)

- Management (meaning management of these resources in order to make them available for tourists)

\section{- Complementary TBRTC components}

- Transportation services

- Border-crossing infrastructure

- Travel banking and insurance

- Tourism-related goods production

- Educational services for tourism-specific industries

- Security and law enforcement

The key elements of each TBRTC are the object of tourism infrastructure, which enable the tourist services existence. Tour operations services ensure that the comprehensive tourism product is delivered to the customers. A significant impact on tourism development within a specific region comes from dedicated transborder tourism projects funded by governments and international funds. A defining role in introducing and implementing these projects and thus in establishing tourism market in a region belongs to institutions and organisation that are the projects applicants. In Euro-regions of Ukraine, these projects are coordinated by regional administrations department of 
Figure 3. Schematic model of a transborder recreational tourism complex (graphics developed by the author)

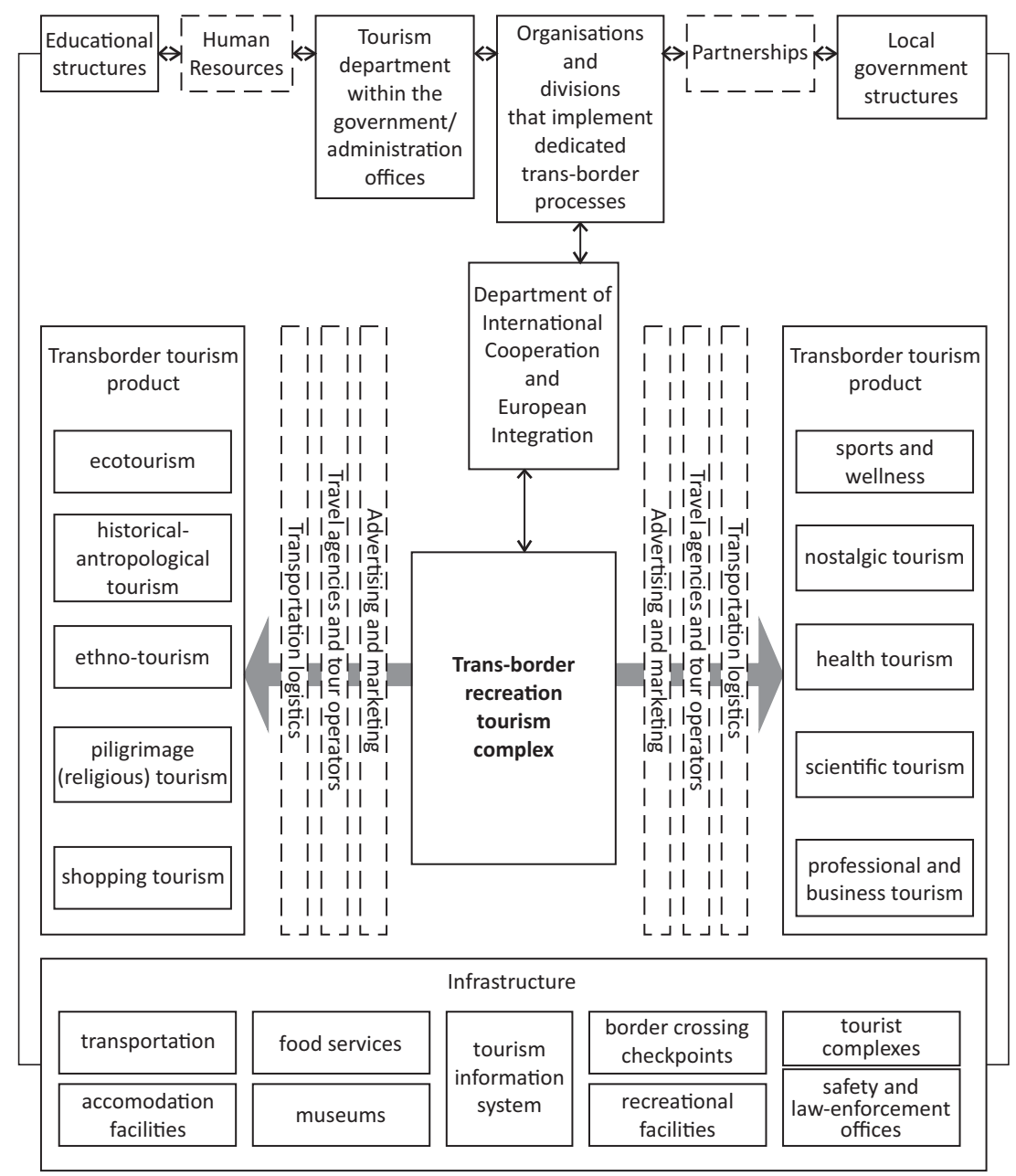

Source: graphics developed by the author

International Collaboration and European Integration. The complete model of a TBRTC takes into account all of the influencing factors and functional components within a specific transborder territory as shown in Figure 3.

\section{TBRTC EXAMPLE IN BUKOVINA-BESSARABIA TRANSBORDER REGION}

The transborder-region of Bukovina-Bessarabia is aligned with Chernivtsi region of Ukraine; North Bukovina/Suceava region of Romania; and north-western regions of Moldova. The region offers a variety of types of tourism and related services making it a good example introducing the concepts of transborder tourism and the related TBRTC. Below, we list the existing and emerging kinds of tourism in Bukovina-Bessarabia region along with a brief definition and a few sample destinations for each kind. 
Ecological tourism. Minimum nature-footprint travel within different ecosystems: the Carpathian Mountains, Dniester-river canyon.

Historical-anthropological tourism. Visiting and exploring historically important landmarks: Khotyn Fortress, Residence of Bukovinian and Dalmatian Metropolitans (now a structure within Chernivtsi National University).

Ethno-cultural tourism. Exploring and participating in traditional events, celebrations, and festivals: Malanka (pre-reform New Year Eve) and Ascent to the Polonyna (traditional annual celebration of moving the cattle herds to the high pastures, or "polonynas", for the summer season).

Pilgrimage tourism. Visiting temples and monasteries: Sucevița and Moldovița monasteries in Southern Bukovina.

Shopping tourism. Visiting shopping destinations of all kinds: "Kalynivka" outdoor market in Chernivtsi, supermarkets and trade outlets in Suceava.

Active tourism. Participating or viewing different kinds of sports active outdoor activities: mountain trekking, white-water rafting in the Carpathian Mountains.

Nostalgic tourism. Visiting family, ancestral residences, cemeteries where ancestors or family are buried: multiple locations.

Health and wellness tourism. Travelling to benefit from differences in healthcare services prices and to access health and recreation resorts. Salt mines recreational resort in Solca and Cacica in Romania.

Scientific tourism. Visiting academic and research institutions. Yury Fedkovych Chernivtsi National University and Ștefan del Mare University of Suceava.

Professional and business tourism. Business trips within commercial and other types of transborder collaborations and travel to conferences and professional shows: multiple locations.

The transborder recreational tourism complex in Bukovina and Bessarabia exhibited remarkable growth in the recent decades. As recently as in the late 1990s, this TBTRC was practically non-existent. Tourist-oriented business was in its infancy despite the demand and significant flow of cross-border travellers in both directions. The rapid growth of last twenty years is explained by the combination of two factors. The first factor is the general change in economies of all participating countries from pre-1990s socialist system, which was dysfunctional and incapable of reacting to market demands in a robust and flexible manner. The second factor is the dedicated effort to develop tourism specifically, which came from a number of grant-funded tourism programs and their support from local administrations and non-government organisations. Unfortunately, we are not aware of systemic analysis of tourism developments along Ukraine-Moldova-Romania borders published in research literature in English. The systematisation above has been prepared by the author and the author's colleagues. Earlier results and used statistic have been published in Ukrainian and in Russian in Puric (2007), Efros et al. (2015), and Buchko (2015a); the first of the cited works has extensive description of the impact of tourism on the Romanian side of the border.

As of early 2020, the information services and the food and accommodation services infrastructure supporting the above-described tourist destinations have been sufficiently developed to support the existing tourism flows. Transportation infrastructure is less developed, yet significant progress has been achieved. The part of the complex that needs the most work is the border-crossing structure, whose development has been upended by the Covid-19-related travel restrictions. However, if the business and 
political trends of the last two decades continue, one can expect that the missing part of the infrastructure will form successfully once the pandemic-era restrictions are lifted.

Similar TBRTC-related processes can be observed in all transborder regions in the western part of Ukraine. These dynamics are reflected in the quantitative and qualitative growth of tourism in Ukraine (Buchko 2018; Buchko, 2020; Bozhuk and Buchko, 2018). Developing tourism is one of the primary implementation directions of the following governmental programs aimed at improving the socioeconomic situation in the transborder union: "Poland-Belarus-Ukraine" program (Volhynian, Transcarpathian, and Lviv regions); "Hungary-Slovakia-Ukraine" program (Transcarpathian region); "Romania-Ukraine-Moldova" program (Transcarpathian, Ivano-Frankivsk, Odessa, and Chernivtsi regions). The result of implementing these programs is improvement in communications and transportation, optimisation of travel information services, improved tourism infrastructure and quality of tourism services, and increase in the volume of international tourist flows.

\section{DisCUSSION}

The presented study systematises both the fundamental research in the geography of tourism and the knowledge accumulated by the author during personal participation in the range of international projects on transborder tourism. Unfortunately, some of the latter includes facts that have not been presented in internationally recognised research journals, only in local academic sources and conference materials. We feel that the wider research community would benefit if anyone prepared a thorough review of such smaller publications and findings, yet such undertaking is clearly outside of the scope of a simple research article. In here, we limit our presentation to referencing the existing local and international information sources.

One partial limitation of the presented research is that it is based only on transborder regions which include Ukraine as one of their parts. We feel that it might be extremely educational to observe TBRTCs created in transborder regions of different countries. We are most interested in seeing such analyses for transborder regions where the border crossings are not regulated by visa and citizenship requirements, such as regions that are fully within the European Union. Our hypothesis is that the lack of border-crossing infrastructural bottlenecks and travel impediments may translate into significantly faster and more efficient development of tourism-recreational complexes. A related partial limitation is that most of the local details of transborder tourism that we describe are related to the Ukrainian side of the border. Some of the cited literature has limited statistics of the changes on the other side, such as Puric (2007), however, we believe that much of the locally-relevant information has simply not been published in the internationally-available sources yet. We are actively developing collaborations with geography of tourism scholars from Romania and Moldova and aim to release a more comprehensive analysis of tourism in Bukovina-Bessarabia trans-border region in the future.

This paper is our introduction of TBTRC concept and, as such, is only the starting point of a larger direction of research we plan to conduct in our future work. We plan to collect more detailed statistics of economic and political changes in the transborder regions extending further into the past, in order to build a better model of how transborder collaboration impacts life and business on all sides of the border. We also plan to 
study TBRTCs in other Euro-regions across the western border of Ukraine and analyse any similarities and differences between them.

\section{CONCLUSION}

We have introduced and described the notion of a transborder recreational tourism complex or TBRTC. A general recreational tourism complex is the combination of tourism-motivating resources such as tourist attractions of different kinds; tourism-enabling infrastructure such as transportation, accommodation, or food services; and tourism-oriented informational services such as tour guides, travel bureaus and so on. In the case of transborder tourism, establishing such a complex poses additional requirements such as a separate category of infrastructure related to border-crossings and high-level of transborder collaboration - political and economic relationship between the near-border regions of the neighbouring countries. We list the basic components of a TBRTC such as food and hotel services and other infrastructure and a number of complimentary components ranging from law enforcement to tourism-oriented education needs. We also systematise different external and internal influences that can impact the formation of a TBRTC, including different demographic, economic, technical, and political factors.

Sustaining the level of transborder tourism within a region is closely related to the formation of TBRTCs. Several such complexes emerged in transborder regions along the western part of Ukraine in the late 1990s in response to the rise of transborder tourism within the former Socialist Block countries and continue to form allowing to sustain and grow active transborder tourism in the region. We use Bukovina-Bessarabia region, which extends across territories of Ukraine, Romania, and Moldova, to illustrate some of the basic concepts of a TBRTC. We find that TBRTC is a convenient tool for modelling both tourism-driven political, economic, social, and cultural changes in near-border regions of neighbouring countries, as well as for understanding the evolution of tourism in response to such political and other changes.

\section{References}

Boonchai, P., Freathy P. (2020). Cross-border tourism and the regional economy: a typology of the ignored shopper. Current Issues in Tourism, 23(5), 626-640.

Bozhuk, T., Buchko, Z. (2018). Cross-Border Ukrainian-Hungarian Cooperationin the Sphere of Tourism. Journal Geolology. Geography. Geoecology, 27(1), 35-42.

Buchko, Z. (2015). Festivals and traditional holidays in the ethnic tourism in Chernivtsi region. Tourist Bucovina, 1, 128-133.

Buchko, Z. (2015a). Transkordonnyi turyzm u konteksti yevrointehratsii Ukrainy [Transborder tourism in the context of Euro-integration of Ukraine], Naukovyi visnyk Chernivetskoho universytetu: zbirnyk naukovykh prats. Heohrafiia, 744-745, 109-111 (in Ukrainian).

Buchko, Z. (2018). Cross-border tourism in Bukovina. Scientific Review of Physical Culture, 8(1), $37-42$.

Buchko, Z. (2020). Cross-Border Ukrainian-Polish Cooperation in the Sphere of Tourism. Economic and Regional Studies, 13(3), 271-283.

Buczek-Kowalik, M., Mitura, T. (2018). Cross-border cooperation of the Polish-Slovak borderland - examples of joint tourism initiatives. Folia Geographica, 60(2), 62-82.

Dołzbłasz, S. (2018). A network approach to transborder cooperation studies as exemplified by Poland's eastern border. Geographia Polonica, 91(1), 63-76.

Efros, V., Buchko, Z., Rudenko, V. (2015). Dosvid realizatsii transkordonnykh proektiv u haluzi turyzmu na Bukovyni [Our experience in implementation of trans-border tourist projects in 
Bukovina]. Heohrafiia, ekolohiia, turyzm: teoriia, metodolohiia, praktyka. Materialy mizhnarodnoi naukovo-praktychnoi konferentsii, 307-309 (in Ukrainian).

Gramberger, M.R. (1999). Rise in cross-border tourism seen as biggest impact of the Euro for citizens in a border region. EUI Review, 1, 14-15.

Karatabanov, R.A., Janaleyeva, K.M., Pashkov, S.V. (2020) Kazakhstan's Multiethnicity: Factor of Inter-Ethnic Tension and Development of Cross-Border Tourism. GeoJournal of Tourism and Geocities, 29(2), 732-745.

Klamár, R., Mika, M. (2015). Foreign tourism in the regions of Slovakia with a focus on Polish visitors. Folia Geographica, 57(2), 40-60.

Kołodziejczyk, K. (2020) Cross-border public transport between Poland and Czechia and the development of the tourism functions of the region. Geographia Polonica, 93(2), 261-285.

Korol, O., Skutar, T. (2019). Theoretical Approaches in the Research of Inbound Tourism: The Case of Bulgaria. GeoJournal of Tourism and Geosites, 26(3), 887-904.

Kozak, M., Buhalis, T. (2019). Cross-border tourism destination marketing: Prerequisites and critical success factors. Journal of Destination Marketing \& Management, 14, 100392.

Krätke, S. (2002). Cross-Border Cooperation and Regional Development in the German-Polish Border Area. Globalization, Regionalization and Cross-Border Regions: scales, discourses and governance, 125-147.

Leimgruber, W. (1998) Defying Political Boundaries: Transborder Tourism in a Regional Context. Visions in Leisure and Business, 17(3), Article 3, 8-29.

Livandovschi, R. (2017). Cross-Border Tourism and its Significance for Tourism Destinations. Eastern European Journal for Regional Studies (EEJRS), Center for Studies in European Integration (CSEI), Academy of Economic Studies of Moldova (ASEM), 3(1), 31-40.

Mikula, N. (2004). Mizhterytorialne ta transkordonne spivrobitnytstvo [Interterritorial and transborder collaboration]. Publication of Institute of Regional Research, National Academy of Science of Ukraine, 395(7), Lviv (in Ukrainian).

Pirozhnik, I. (2020). Tourist Clusters as a Factor in Activating Cross-Border Spatial Development. Prace Komisji Geografii Przemysłu Polskiego Towarzystwa Geograficznego, 34(3), 7-21.

Puric, S., (2007). Rumyno-ukrainskoe transhranichnoe sotrudnichestvo. Shahi k dobrososedstvu [Romanian-Ukrainian trans-border collaboration. Steps to good neighbour relations]. Viche, 6, 74-87 (in Russian)

"Register of European Groupings of Territorial Cooperation". Committee of the Regions. Retrieved from https://portal.cor.europa.eu/egtc/CoRActivities/Pages/egtc-map.aspx

"Regulation (EC) No 1082/2006 of the European Parliament and of the Council of 5 July 2006 on a European grouping of territorial cooperation (EGTC)". European Union Official Website. URL: http://ec.europa.eu/regional_policy/sources/docoffic/official/regulation/pdf/2007/ gect/ce_1082(2006)_en.pdf.

Ried, W., Marschall, P. (2016). Potential Benefits of Crossborder Health Care: The Case Of Poland And Germany. Economics and Sociology, 9(3), 14-27.

Rudawska, I., Fedorowski, J. (2016). Cross-Border Care and Cooperation. Economics and Sociology, 9(3), 11-13.

Sofield, T.H.B. (2006) Border Tourism and Border Communities: An Overview. Tourism Geographies, 8(2), 102-121.

Stoffelen, A. (2017) Tourism and Cross Border Regional Development: Insights in European Contexts. European Planning Studies, 25(6), 1013-1033.

Stoffelen, A., Vanneste, D. (2018) The role of history and identity discourses in cross-border tourism destination development: A Vogtland case study. Journal of Destination Marketing \& Management, 8, 204-213.

State strategy of regional development until 2027 (2020). Kyiv: Verkhovna Rada of Ukraine. Retrieved from https://zakon.rada.gov.ua/laws/show/695-2020-п\#Text

State strategy of transborder collaboration development for 2021-2027 (2021). Kyiv: Ver-khovna Rada of Ukraine. Retrieved from https://zakon.rada.gov.ua/laws/show/408-2021-п\#Text

Strategy of development of tourism and recreation until 2026 (2017). Kyiv: Verkhovna Rada of Ukraine. Retrieved from https://zakon.rada.gov.ua/laws/show/168-2017-p\#Text

Strategy project of sustained development of Ukraine until 2030 (2018). Kyiv: Legislation of Ukraine. Retrieved from http://search.ligazakon.ua/__doc2.nsf/link1/JH6YF00A.html 
Studzieniecki, T, Palmowski, T, Korneevetsc, V. (2016). The system of cross-border tourism in the Polish-Russia borderland. Procedia Economics and Finance, 39, 545-552.

Studzieniecki, T, Spiriajevas, E. (2019). Cross-Border Tourist Destinations In Europe - Genesis, Essence And Promotion. Proceedings of Varazdin 46th International Scientific Conference on Economic and Social Development - "Sustainable Tourist Destinations", 341-354.

Tătar, C., Studzieniecki, T., Czimre, K., Pénzes, J. (2020) Marketing awareness of crossborder destination -the case study of bihor-hajdu/bihar euroregion. Geojournal of Tourism and Geosites, 28(1), 95-103.

Więckowski, M. (2010). Tourism development in the borderlands of Poland. Geographia Polonica, 83(2), 67-81.

Więckowski, M., Saarinen, J. (2019). Tourism transitions, changes, and the creation of new spaces and places in Central-Eastern Europe. Geographia Polonica, 92(4), 369-377.

Żemła, M.,Ziółkowska-Weiss, K. (2017). Turystyka między krajami grupy Wyszehradzkiej. Wybrane problemy i perspektywy na przyszłość. Prace Naukowe Uniwersytetu Ekonomicznego we Wrocławiu, 473, 637-647.

Zhanna Buchko, PhD is a professor and the Head of the Department of Social Geography and Recreational Nature Management of the Yuriy Fedkovych Chernivtsi National University in Chernivtsi, Ukraine. Dr. Buchko's interests in geography span from cartography to branches of economic geography related to geography of tourism. Her main areas of research are transborder tourism, ecotourism, ethno-tourism, and aesthetic potential of landscapes, primarily applied to border regions of Western Ukraine. She is a member of the Ukrainian Geographical Society.

ORCID: https://orcid.org/0000-0003-0066-9284

\section{Address:}

Yuriy Fedkovych Chernivtsi National University

2 Kotsyubynskyi Str.

58012 Chernivtsi, Ukraine

e-mail: zh.buchko@chnu.edu.ua 